

(RESEARCH ARTICLE)

\title{
Preliminary study of the avifauna of the families Numididae and Phasianidae (Galliformes) of the Bombo-Lumene hunting area and reserve in Kinshasa (DR Congo)
}

Jean Victor Tshisuku Milolo 1, 2, *, Dieudonné Musibono Eyul'anki 2, Constantin Lubini Ayingweu 2 and Séraphin Ifuta Ndey Bibuya ${ }^{2}$

${ }^{1}$ Biology Laboratory, Department of Biology and Applied Techniques, Superior Pedagogical Institute of the Gombe (ISP/G), P.O. BOX 3580 Kinshasa, D.R Congo.

2 Department of Environmental Sciences, Faculty of Sciences, University of Kinshasa (UNIKIN), P.O. BOX. 190 Kinshasa XI, D.R Congo.

World Journal of Advanced Research and Reviews, 2021, 12(02), 019-031

Publication history: Received on 13 September 2021; revised on 19 October 2021; accepted on 21 October 2021

Article DOI: https://doi.org/10.30574/wjarr.2021.12.2.0529

\begin{abstract}
The present study consisted of the identification of Numididae and Phasianidae birds of the Bombo-Lumene Hunting Estate and Reserve with a view to a domestication trial of one or two of their species. It focuses on direct field observations and trapping of birds. The following parameters were targeted in relation to domestication: weight, size, diet of these birds. A total of 468 bird specimens were observed (105) and captured (363) in various habitats. Of the individuals captured, 31 or $8.5 \%$ were Numididae and 332 or $91.4 \%$ were Phasianidae. The identification revealed five (5) species, three (3) genera, two (2) families and a single order. The species Francolinus afer, Numida meleagris and Francolinus coqui are the richest with respectively 364 individuals, 58 individuals and 42 individuals. On the other hand, the species Guttera pucherani and Francolinus streptophorus are the least rich with three individuals and one individual respectively. As millet farming has already been successfully experimented elsewhere and in the Democratic Republic of Congo, the results obtained from the targeted parameters indicate that among the species identified, only the species Guttera pucherani (Numididae) and Francolinus afer (Phasianidae) are eligible for a domestication trial in the Democratic Republic of Congo.
\end{abstract}

Keywords: Diversity; Poultry fauna; Numididae; Phasianidae; Bombo-Lumene Hunting Estate; Reserve; Kinshasa

\section{Introduction}

Population counts have gained considerable importance in ornithology in recent years; there is little ecological research that does not currently involve the use of accurate numerical data on avian population densities and their fluctuations in time and space [1].

The knowledge of the numerical importance of populations, their composition and structure, and the carrying capacity of a given area requires counts and censuses of various types. Moreover, the preservation of birds, which has become so worrying all over the world, requires the most precise possible evaluation of the numbers of threatened species, and most of them are threatened in some way, all the more useful as these data are always largely overestimated. The same is true for maintaining game bird populations at as high a level as possible, taking into account the habitat [2].

\footnotetext{
${ }^{*}$ Corresponding author: Jean Victor Tshisuku Milolo

Biology Laboratory, Department of Biology and Applied Techniques, Superior Pedagogical Institute of the Gombe (ISP/G), P.O. BOX 3580 Kinshasa, D.R Congo.

Copyright (C) 2021 Author(s) retain the copyright of this article. This article is published under the terms of the Creative Commons Attribution Liscense 4.0.
} 
The Democratic Republic of Congo (DRC) IS a country the size of a subcontinent $\left(2,345,410 \mathrm{~km}^{2}\right)$ with significant natural wealth. It IS one of the ten megadiverse countries in the world, an advantage due to the diversity of its ecological and climatic sites, important factors in the distribution of taxa. Birds constitute one of these natural riches, many of which are confined to the herbaceous formations, forests and forest galleries; the parks of the East of the DRC and hunting domains and reserves of the country, notably the Hunting Estate and Reserve of Bombo-Lumene (DCRBL). The majority of the avifauna of this domain remains little known and less studied by scientists [3].

The Bombo-Lumene Hunting Area and Reserve offers a diversity of landscapes: extensive plateaus and open areas, hills, wet valleys, extensive agrarian surfaces, villages on the periphery. Its vegetation consists of shrubby herbaceous formations dominated mainly by Poaceae (fats) and Fabaceae (vegetable) [4]. The fields installed by the local rural communities and the city dwellers of Kinshasa offer the best food and habitat conditions for vertebrates and insects. Birds are omnivorous animals that eat almost all types of food: seeds, fruits, tubers, leaves, flowers, and insects.

For a very long time, birds have been considered a source of food, clothing and manifestation of religious and social culture, art and sport [1]. In Kinshasa, the capital of the Democratic Republic of Congo (DRC), recent studies by Punga \& Ifuta [5] revealed about 131 species of birds grouped into 40 families, representing $11 \%$ of the species inventoried in the whole DRC. Among them are the Numididae and Phasianidae, birds of open environments and forest galleries. Can the Bombo-Lumene Hunting Estate and Reserve, an integral part of the city of Kinshasa, harbor Numididae and Phasianidae birds that could be domesticated in the DRC? This study on the avifauna of the families Numididae and Phasianidae (Galliformes) of this protected area therefore attempts to answer this concern.

\section{Study environment, materials and methods}

\subsection{Study environment}

This study was conducted in the Bombo-Lumene Hunting Estate and Reserve (Figure 1), a protected area located in the extreme north of the Commune of Maluku, $\pm 130 \mathrm{~km}$ from the city of Kinshasa in the Democratic epublic of Congo. The reserve is located between $4^{\circ} 20^{\prime}$ and $5^{\circ} 80^{\prime}$ East longitude and between $15^{\circ} 50^{\prime}$ and $16^{\circ} 20^{\prime}$ South latitude.



Figure 1 Map of the city of Kinshasa including the hunting Estate and Reserve of Bombo-Lumene

The reserve takes its name from two rivers: Bombo and Lumene, which cross its natural boundaries as follows [4]:

- To the north: National road number one that leads from Kinshasa to Kenge from where it is crossed by the Bombo River to where it is crossed again by the Lufimi River;

- In the East: from the Lufimi River to where it crosses the Kinshasa-Kenge road upstream to its tributary with the Idiondo River, the southern limit of the territory of Kasangulu; 
- In the West: the Bombo River, from the Kinshasa-Kenge national road number one to its confluence with the Muti-Mutiene and Mpili Rivers to its southern source;

- In the South: the southern limit of the territory of Kasangulu.

Located in the city of Kinshasa, the hunting Estate and Reserve of Bombo-Lumene has a hot and humid tropical climate of type AW4 according to the classification of Köppen where the average temperature varies from $22.5^{\circ} \mathrm{C}$ to $25^{\circ} \mathrm{C}$. There are two seasons: the main rainy season (September to mid-May) and the dry season (mid-May to August) [6]. The soil is mainly sandy and is of little use for agricultural activities. Thus, no agricultural products characterize this province which is supplied with agricultural products from the provinces of Kongo Central, Kwango, Kwilu, Mai-Ndombe, Equateur and others [7].

\subsection{Biological material}

Four hundred and sixty-eight (468) specimens of birds observed and captured constitute the biological material of this study on which are based the scientific identifications and characterizations of the birds Numidae and Phasianidae inhabiting the reserve.

\subsection{Methodology}

\subsubsection{Direct observations and capture of birds}

We used direct observations of the target birds by walking slowly in the sites frequented by groups of active Numididae and Phasianidae birds: pecking insects (ants, termites, crickets, butterflies, grasshoppers, etc.), seeds, fruits, cassava tubers, etc.

The observations of the birds were carried out from 5:30 a.m. to 6:30 p.m. with a break from 12:00 p.m. to 2:30 p.m., during which time the birds were resting. At the end of each day, the number of individuals observed and the habitat in which the birds were observed were noted. This allowed us to get an idea of the abundance index and to obtain the species richness. Birds were captured with the help of hunters using the baited and unbaited trapping technique at several sites around the study area.

\subsubsection{Measurement, weighing and systematic identification of birds}

The measurement and weighing of the birds were carried out on each specimen thanks to a graduated batten with a range of $30 \mathrm{~cm}$ and an electronic balance $(0,1 \mathrm{~g}$ of precision). The birds observed and/or captured were identified on site using the determination keys proposed by Borrow and Demey [8]; [9]. After identification, the different specimens were photographed with a professional digital camera branded Canon Rebel, Canon Zoom LENS 18-150 mm.

\subsubsection{Determination of diet}

The diet of Numididae and Phasianidae birds was determined at the Laboratory of Aquatic Environment Studies (LEMA) of the Superior Pedagogical Institute of the Gombe in Kinshasa. The dissection of 40 birds including 8 Numididae and 32 Phasianidae taken at random among the captured birds allowed the qualitative and quantitative analysis of the substances contained in the gizzards of the birds.

The gizzards were separated from the digestive tracts and preserved in jars containing a $5 \%$ formalin solution and labeled (registration number, date and name of the bird). The extracted gizzards and their contents were then weighed on Electronic balance, model WT $26101 \mathrm{~K}$, accuracy $0.1 \mathrm{~g}$. The contents of each gizzard were emptied into a petri dish for sorting and each substrate was weighed on a Jewerly Scale GEM 20 electronic balance and then observed with the naked eye and/or a binocular magnifying glass, Optika brand, at 40x magnification.

Qualitatively, we used the Degree of Presence method used by Mulotwa [10]. It consists in recording the number of times the substrate appeared in the set of non-empty gizzards whose numbers correspond to the number of birds analyzed.

From a quantitative point of view, we used the formula proposed by Dajoz and used by Mulotwa [10]; [11] to obtain the relative frequency of ingested substrates identified in the stomach contents of birds by applying the following formula: $\operatorname{Fr}(\%)=\mathrm{Na} / \mathrm{Nx} 100$. The arithmetic mean of appearance of ingested food category was calculated by the formula: $\mathrm{X}=$ $\Sigma \mathrm{Na} / \mathrm{N}$ where, $\mathrm{X}$ is the mean, $\mathrm{Na}$ expresses the number of appearance and $\mathrm{N}$ is the total number of appearance of ingested food categories. 


\subsubsection{Calculated indices}

Two indices have been studied to determine the structure of the bird population:

- Relative abundance or index of abundance: calculated from the formula: $\mathrm{RA}=\mathrm{Ni} / \mathrm{Nx} 100$. It was evaluated at the level of families, genera and species of birds identified. It is based on the encounter rate, that is, the number of individuals and groups involved according to the number of days during which the species was recorded.

- Species richness: this was calculated to indicate the number of individuals recorded by target bird species.

\subsubsection{Analyse statistique et traitement des données}

The different data from observations, capture, measurement and weighing, analysis of stomach contents of birds Numididae and Phasianidae were encoded on the Excel 2013 spreadsheet. The results obtained are presented in tables and graphs for interpretation. The Origin 6.1 software was used to draw the graphs and the cartography of the BomboLumene Hunting Area and Reserve was generated with ArcGis 10.8 software.

\section{Results}

\subsection{Numididae and Phasianidae bird species inventoried in the DCRBL}

The list of bird species of the families Numididae and Phasianidae identified in the Bombo-Lumene Hunting Area and Reserve in the framework of this study is given in Table 1.

Table 1 List of Numididae and Phasianidae birds identified in the DCRBL

\begin{tabular}{|c|c|c|c|}
\hline Order & Family & Genus & Species \\
\hline \multirow{3}{*}{ Galliformes } & \multirow[t]{2}{*}{ Numididae } & Numida & Numida meleagris Linnaeus, 1758 \\
\hline & & Guttera & Guttera pucherani Hartlaub, 1861 \\
\hline & Phasianidae & Francolinus & $\begin{array}{l}\text { Francolinus afer Statius Muller, } 1776 \\
\text { Francolinus coqui Smith, } 1836 \\
\text { Francolinus streptophorus Ogilvie-Grant, } 1891\end{array}$ \\
\hline 1 & 2 & 3 & 5 \\
\hline
\end{tabular}

Five (5) species of birds belonging to a single order (Galliformes), two families (Numididae and Phasianidae) and three genera (Numida, Guttera and Francolinus) are identified in the Bombo-Lumene Hunting Area and Reserve.

\subsubsection{Relative abundance of identified bird families}

It emerges from the results visualized in figure 2 that the birds of the Numidae family are the most numerous in terms of genera with $66,7 \%$, that is to say two genera (Numida and Guttera) than the Phasianidae with $33,3 \%$, that is to say one genus (Francolinus).

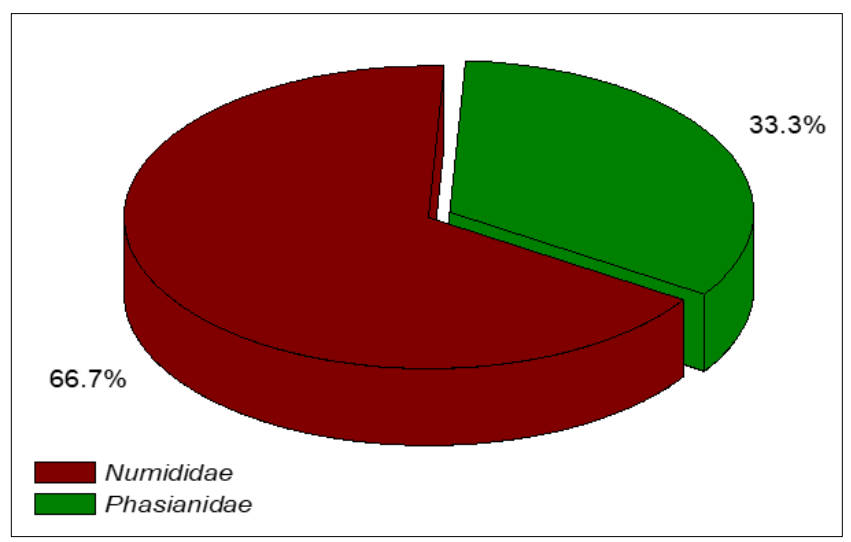

Figure 2 Relative abundance (\%) of families of identified birds 


\subsubsection{Relative abundance of genera of identified birds}

Of the three genera of birds identified in the Bombo-Lumene Game Reserve, the genus Francolinus with $60 \%$ or three species (Francolinus afer Statius Muller, 1776; F. coqui Smith, 1836 and F. streptophorus Ogilvie-Grant, 1891) is the most representative, followed by the genera Numida and Guttera with respectively one species or 20\% (Figure 3).

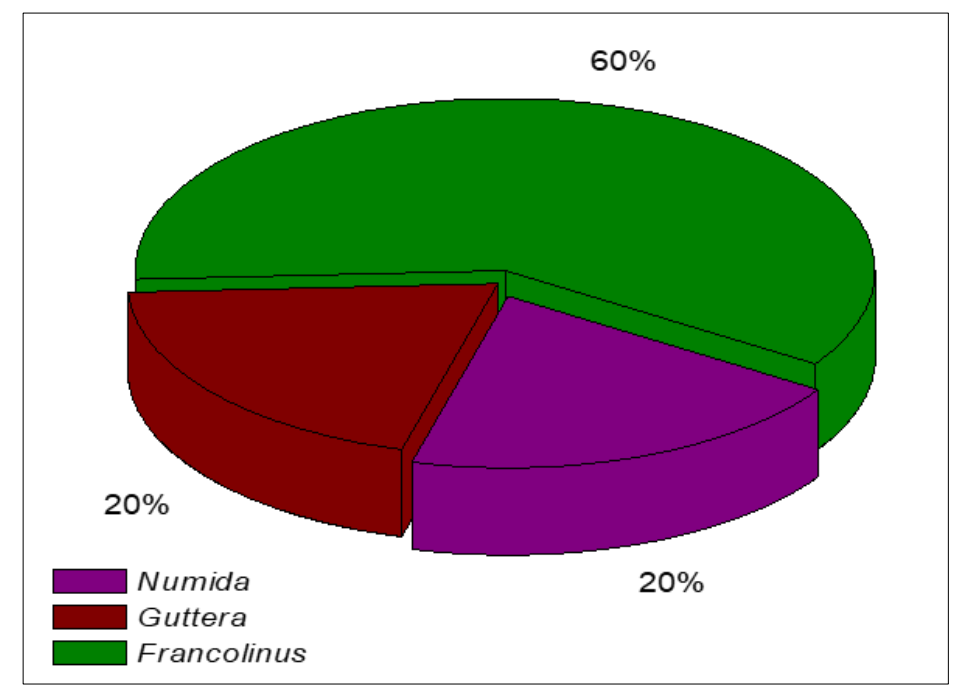

Figure 3 Relative abundance (\%) of genera of identified birds

\subsubsection{Abondance relative des espèces des oiseaux identifies}

Out of 468 specimens of Numididae and Phasianidae birds observed and collected, the species Francolinus afer Statius Muller, 1776 presents the greatest number of specimens with 364 individuals or $78 \%$ followed by Numida meleagris Linnaeus, 1758 with 58 specimens or 12\%, Francolinus coqui Smith, 1836 with 42 individuals or 9\% and Guttera pucherani Hartlaub, 1861 with 3 specimens or 1\%. Francolinus streptophorus Ogilvie-Grant, 1891 presents a low percentage, white one individual observed (figure 4).

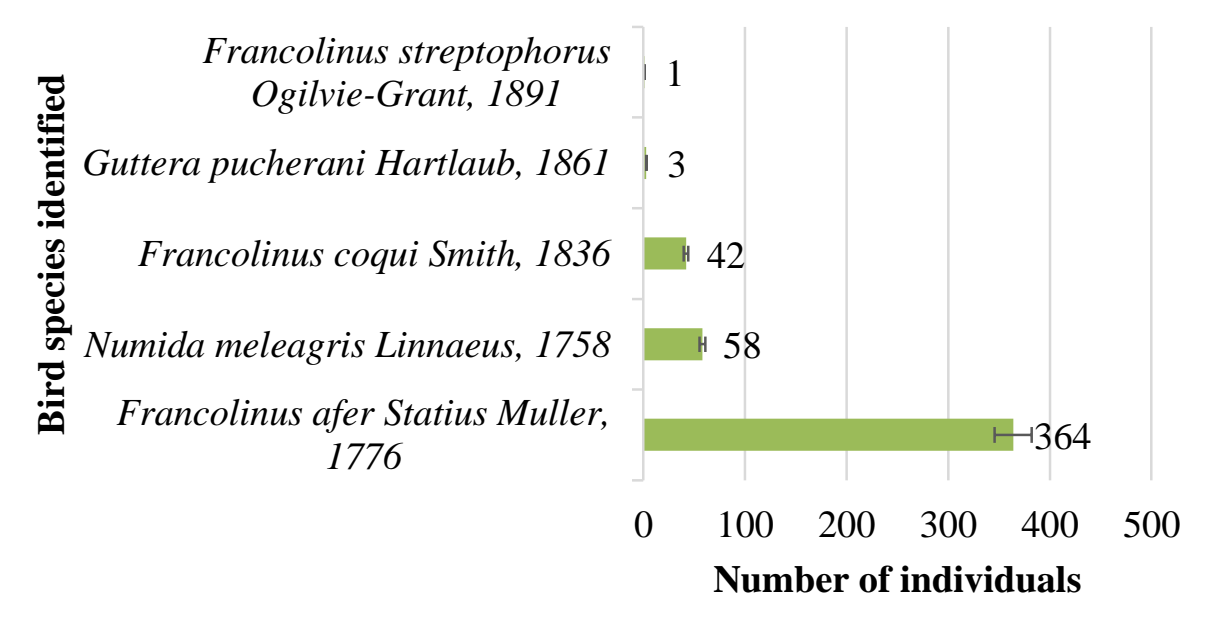

Figure 4 Relative frequency of species of identified birds

\subsection{Distribution of Numididae and Phasianidae birds observed at the DCRBL sites}

The distribution of Numididae and Phasianidae birds inventoried in the Bombo-Lumene Hunting Area and Reserve according to study sites is shown in Table 2. 
World Journal of Advanced Research and Reviews, 2021, 12(02), 019-031

Table 2 Distribution of Numididae and Phasianidae birds surveyed according to study sites (Gal-forest = Forest gallery)

\begin{tabular}{|c|c|c|c|c|c|c|c|c|}
\hline \multirow{3}{*}{ Period } & \multirow{3}{*}{ Species } & \multicolumn{7}{|c|}{ Sites } \\
\hline & & Bibale & Linzombi & Mua & $\begin{array}{c}\text { Site } \\
\text { DCRBL }\end{array}$ & Fields & $\begin{array}{l}\text { Gal- } \\
\text { forest }\end{array}$ & $\begin{array}{l}\text { Treeless } \\
\text { areas }\end{array}$ \\
\hline & & \multicolumn{7}{|c|}{ Observed numbers } \\
\hline $\begin{array}{c}\text { September } \\
2019\end{array}$ & $\begin{array}{l}\text { 1. N. meleagris } \\
\text { 2. G. pucherani } \\
\text { 3. F. afer } \\
\text { 4. F. coqui } \\
\text { 5. F. } \\
\text { streptophorus }\end{array}$ & $\begin{array}{l}- \\
- \\
3 \\
- \\
-\end{array}$ & $\begin{array}{l}- \\
- \\
- \\
- \\
-\end{array}$ & $\begin{array}{l}3 \\
- \\
- \\
- \\
-\end{array}$ & $\begin{array}{c}\text { Several } \\
\text { troops } \\
- \\
- \\
-\end{array}$ & $\begin{array}{l}- \\
- \\
3 \\
4 \\
-\end{array}$ & $\begin{array}{l}- \\
- \\
- \\
- \\
-\end{array}$ & $\begin{array}{l}- \\
- \\
3 \\
- \\
-\end{array}$ \\
\hline $\begin{array}{l}\text { December } \\
2019\end{array}$ & $\begin{array}{l}\text { 1. N. meleagris } \\
\text { 2. G. pucherani } \\
\text { 3. F. afer } \\
\text { 4. F. coqui } \\
\text { 5. F. } \\
\text { streptophorus }\end{array}$ & $\begin{array}{l}- \\
- \\
2 \\
- \\
-\end{array}$ & $\begin{array}{l}- \\
- \\
- \\
- \\
-\end{array}$ & $\begin{array}{l}- \\
- \\
- \\
- \\
-\end{array}$ & $\begin{array}{c}\text { Several } \\
\text { troops } \\
- \\
- \\
-\end{array}$ & $\begin{array}{l}- \\
- \\
- \\
- \\
-\end{array}$ & $\begin{array}{l}- \\
1 \\
- \\
- \\
-\end{array}$ & $\begin{array}{c}5 \\
- \\
11 \\
5 \\
-\end{array}$ \\
\hline $\begin{array}{c}\text { Febuary } \\
2021\end{array}$ & $\begin{array}{l}\text { 1. N. meleagris } \\
\text { 2. G. pucherani } \\
\text { 3. F. afer } \\
\text { 4. F. coqui } \\
\text { 5. F. } \\
\text { streptophorus }\end{array}$ & $\begin{array}{l}5 \\
- \\
- \\
4 \\
-\end{array}$ & $\begin{array}{l}- \\
- \\
3 \\
- \\
-\end{array}$ & $\begin{array}{l}- \\
- \\
- \\
- \\
-\end{array}$ & $\begin{array}{c}\text { Several } \\
\text { troops } \\
- \\
- \\
-\end{array}$ & $\begin{array}{l}- \\
- \\
- \\
- \\
-\end{array}$ & $\begin{array}{l}- \\
- \\
- \\
- \\
-\end{array}$ & $\begin{array}{l}- \\
- \\
7 \\
- \\
-\end{array}$ \\
\hline $\begin{array}{c}\text { October } \\
2020\end{array}$ & $\begin{array}{l}\text { 1. N. meleagris } \\
\text { 2. G. pucherani } \\
\text { 3. F. afer } \\
\text { 4. F. coqui } \\
\text { 5. F. } \\
\text { streptophorus }\end{array}$ & $\begin{array}{l}- \\
- \\
3 \\
- \\
-\end{array}$ & $\begin{array}{l}- \\
- \\
2 \\
- \\
-\end{array}$ & $\begin{array}{l}- \\
- \\
- \\
- \\
-\end{array}$ & $\begin{array}{c}\text { Several } \\
\text { troops } \\
- \\
- \\
-\end{array}$ & $\begin{array}{l}9 \\
- \\
- \\
5 \\
-\end{array}$ & $\begin{array}{l}- \\
- \\
- \\
- \\
-\end{array}$ & $\begin{array}{l}- \\
- \\
4 \\
- \\
-\end{array}$ \\
\hline $\begin{array}{c}\text { December } \\
2020\end{array}$ & $\begin{array}{l}\text { 1. N. meleagris } \\
\text { 2. G. pucherani } \\
\text { 3. F. afer } \\
\text { 4. F. coqui } \\
\text { 5. F. } \\
\text { streptophorus }\end{array}$ & $\begin{array}{l}- \\
- \\
2 \\
- \\
-\end{array}$ & $\begin{array}{l}- \\
- \\
- \\
- \\
1\end{array}$ & $\begin{array}{l}- \\
- \\
- \\
1 \\
-\end{array}$ & $\begin{array}{l}7 \\
- \\
- \\
- \\
-\end{array}$ & $\begin{array}{l}- \\
- \\
4 \\
4 \\
-\end{array}$ & $\begin{array}{l}- \\
1 \\
- \\
- \\
-\end{array}$ & $\begin{array}{l}- \\
- \\
3 \\
- \\
-\end{array}$ \\
\hline \multicolumn{2}{|l|}{ Total } & 19 & 6 & 4 & 7 & 29 & 02 & 38 \\
\hline \multicolumn{2}{|c|}{ Percentage (\%) } & 18 & 5,7 & 3,8 & $\begin{array}{c}6,6 \\
\text { Several } \\
\text { troops }\end{array}$ & 27,6 & 1,9 & 36,1 \\
\hline
\end{tabular}

Analysis of the results reveals that many Numididae and Phasianidae birds at the DCRBL were observed in treeless areas or open areas (36.1\%), in food crop fields (27.6\%), on the Bibale trail (18\%), on the site (6.6\%), on the Linzombi (5.7\%) and Mua (3.8\%) trails, and finally in the forest galleries (1.9\%). The species richness of the observed species is 50 individuals or $47.6 \%$ for Francolinus afer, 30 individuals or $28.5 \%$ for Numida meleagris, 23 individuals or $21.3 \%$ for Francolinus coqui and finally 1 individual or $0.9 \%$ for Guttera pucherani and Francolinus streptophorus respectively. 


\subsection{Distribution of Numididae and Phasianidae birds captured according to sites on the periphery of the protected area}

Table 3 shows the distribution of Numididae and Phasianidae birds captured in the periphery of the protected area (PA).

Table 3 Distribution of Numididae and Phasianidae birds in the periphery of the PA (Sep = September, Dec = December, Feb = February)

\begin{tabular}{|c|c|c|c|c|c|c|c|c|c|c|}
\hline \multirow[b]{2}{*}{ Period } & \multirow[b]{2}{*}{ Sites } & \multirow[b]{2}{*}{ Species } & \multicolumn{6}{|c|}{ Types of habitats } & \multirow[t]{2}{*}{ Workforce } & \multirow[t]{2}{*}{ Total } \\
\hline & & & Field/Crops & $\begin{array}{l}\text { Treeless } \\
\text { area }\end{array}$ & \begin{tabular}{|l} 
Grassy \\
Savanna
\end{tabular} & \begin{tabular}{|l} 
Forestry \\
gallery
\end{tabular} & Plain & $\begin{array}{l}\text { Wooded } \\
\text { savannah }\end{array}$ & & \\
\hline $\begin{array}{c}\text { Sep } \\
2019\end{array}$ & 1. Nsuni & \begin{tabular}{|lr} 
1. F. afer \\
2. F. \\
3. $r o q u i$ \\
meleagris
\end{tabular} & $\begin{array}{l}x(9) \\
x(2) \\
x(4)\end{array}$ & $\begin{array}{l}- \\
- \\
-\end{array}$ & $\begin{array}{l}x(7) \\
x(1) \\
-\end{array}$ & $\begin{array}{l}- \\
- \\
-\end{array}$ & $\begin{array}{l}- \\
- \\
-\end{array}$ & $\begin{array}{c}- \\
- \\
x(2)\end{array}$ & $\begin{array}{l}- \\
- \\
-\end{array}$ & $\begin{array}{c}16 \\
3 \\
6\end{array}$ \\
\hline $\begin{array}{c}\text { Dec } \\
2019\end{array}$ & $\begin{array}{l}\text { 2. Muti- } \\
\text { Mutieni }\end{array}$ & $\begin{array}{l}1 . \quad N . \\
\text { meleagris } \\
\text { 2. F. }\end{array}$ & $\begin{array}{l}x(2)) \\
x(16)\end{array}$ & - & $\begin{array}{c}- \\
x(7)\end{array}$ & - & - & - & $\begin{array}{l}x(1) \\
x(5)\end{array}$ & $\begin{array}{c}3 \\
28\end{array}$ \\
\hline $\begin{array}{l}\mathrm{Fev} \\
2020\end{array}$ & $\begin{array}{c}3 . \\
\text { Mbankana }\end{array}$ & $\begin{array}{l}\text { 1. F. } \text { afer } \\
\text { 2. } \quad N \text {. } \\
\text { meleagris } \\
\text { 3. F. } \text { coqui }\end{array}$ & $\begin{array}{l}x(62) \\
x(7) \\
x(2)\end{array}$ & $\begin{array}{c}X(49) \\
- \\
-\end{array}$ & $\begin{array}{c}- \\
- \\
x(1)\end{array}$ & $\begin{array}{l}- \\
- \\
-\end{array}$ & $\begin{array}{l}- \\
- \\
-\end{array}$ & $\begin{array}{c}- \\
x(4) \\
-\end{array}$ & $\begin{array}{c}x(53) \\
- \\
x(1)\end{array}$ & $\begin{array}{c}164 \\
11 \\
4\end{array}$ \\
\hline $\begin{array}{l}\text { Oct } \\
2020\end{array}$ & $\begin{array}{c}4 . \\
\text { Buantaba }\end{array}$ & \begin{tabular}{|l|} 
1. F. afer \\
2. F. coqui \\
3. $r$ G. \\
pucherani
\end{tabular} & $\begin{array}{c}\mathrm{x}(40) \\
- \\
-\end{array}$ & $\begin{array}{c}- \\
x(5) \\
-\end{array}$ & $\begin{array}{c}\mathrm{x}(28) \\
- \\
-\end{array}$ & $\begin{array}{c}- \\
- \\
x(1)\end{array}$ & $\begin{array}{c}- \\
x(2) \\
- \\
\end{array}$ & $\begin{array}{l}- \\
- \\
-\end{array}$ & $\begin{array}{l}- \\
- \\
-\end{array}$ & $\begin{array}{c}68 \\
7 \\
1\end{array}$ \\
\hline $\begin{array}{c}\text { Dec } \\
2020\end{array}$ & 5. Mbiene &  & $\begin{array}{c}- \\
x(27) \\
x(5) \\
-\end{array}$ & $\begin{array}{c}\mathrm{x}(8) \\
- \\
- \\
-\end{array}$ & $\begin{array}{c}- \\
\mathrm{x}(11) \\
- \\
-\end{array}$ & $\begin{array}{c}- \\
- \\
- \\
x(1)\end{array}$ & $\begin{array}{l}- \\
- \\
- \\
-\end{array}$ & $\begin{array}{l}- \\
- \\
- \\
-\end{array}$ & $\begin{array}{l}- \\
- \\
- \\
-\end{array}$ & $\begin{array}{c}8 \\
38 \\
5 \\
1\end{array}$ \\
\hline & Total & & 176 & 62 & 55 & 02 & 02 & 06 & 60 & 363 \\
\hline
\end{tabular}

From the results in the table above, it appears that Numididae and Phasianidae birds were captured most in Mbankana with 179 individuals or $49.3 \%$, followed by Buantaba with 76 specimens or $20.4 \%$, Mbiene with 52 individuals or $14.3 \%$, Muti-Mutiene with 31 specimens or $8.5 \%$ and finally Nsuni with 25 specimens or $8 \%$. The species richness of the birds captured was 314 individuals for Francolinus afer, whit 86.5\%, 28 individuals for Numida meleagris, whit $7.7 \%, 19$ individuals for Francolinus coqui, whit $5.2 \%$ and 2 individuals for Guttera pucherani, whit $0.5 \%$. These same results also indicate that these birds, all species combined, frequented and were captured in crop fields (176 specimens), treeless areas (62 specimens), fallow land (60 specimens), grassy savannah (55 specimens), wooded savannah (6 specimens), plateaus ( 2 specimens) and the forest gallery ( 2 specimens).

\subsection{Study of the diet}

\subsubsection{Proportions of stomach contents identified in gizzards of Numida meleagris}

From the results in Figure 5, it appears that quantitatively, seeds of wild plants (22.60\%) are the most consumed by Numida meleagris, followed by seeds of food crops of groundnut (Arachis hypogea) (10.06\%), bean (Phaseolus vulgaris) (2.9\%), insect debris (1.4\%). Fragments of unidentified leaves (0.68\%), Panicum caryopsis $(0.44 \%)$ are the least abundant. Pebbles and sand as well as unknown digested substances represent respectively $34.2 \%$ and $24.4 \%$. 


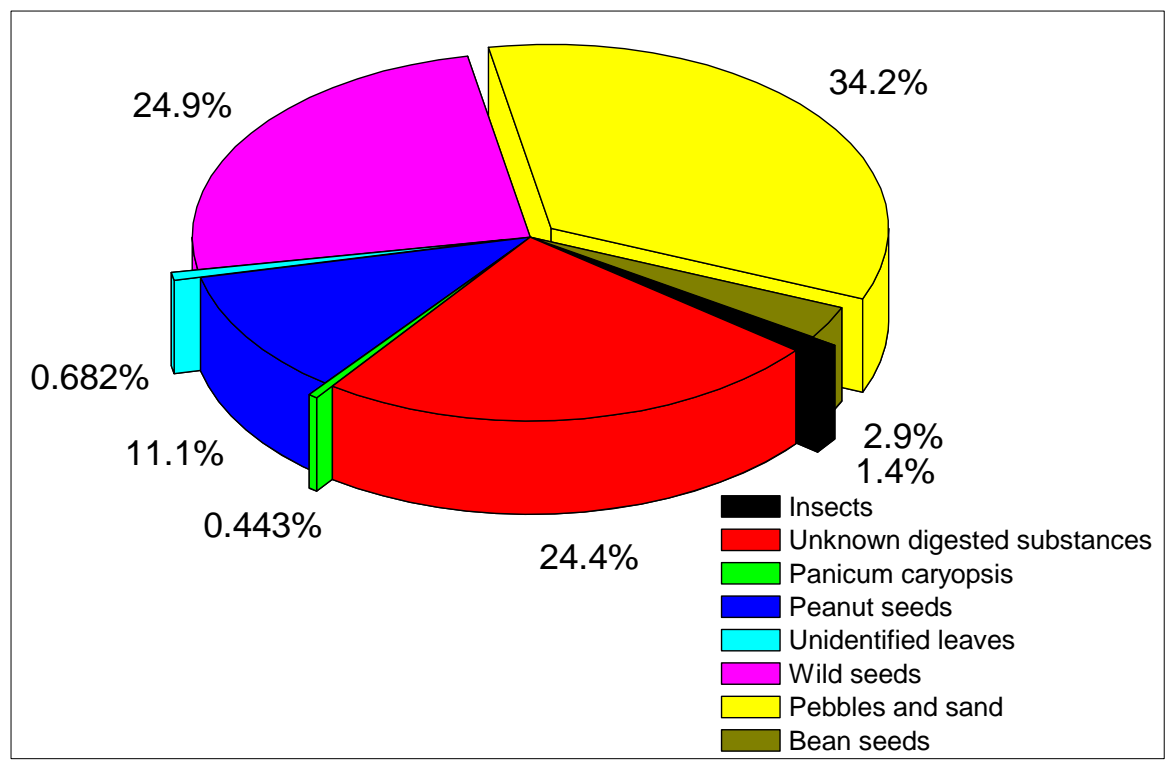

Figure 5 Proportion (\%) of stomach contents identified in gizzards of Numida meleagris

\subsubsection{Proportion of contents identified in the gizzards of Guttera pucherani}

Analysis of the results in Figure 6 informs that quantitatively, Guttera pucherarni consumes seeds of wild plants (26.1\%) in large quantities compared to digested unknown fruit fragments $(10.9 \%)$, insect debris $(1.3 \%)$ and unidentified leaf fragments (0.03\%). In contrast, digested unknown substances (30.9\%) and rocks and sand represent (30.8\%) are more abundant.

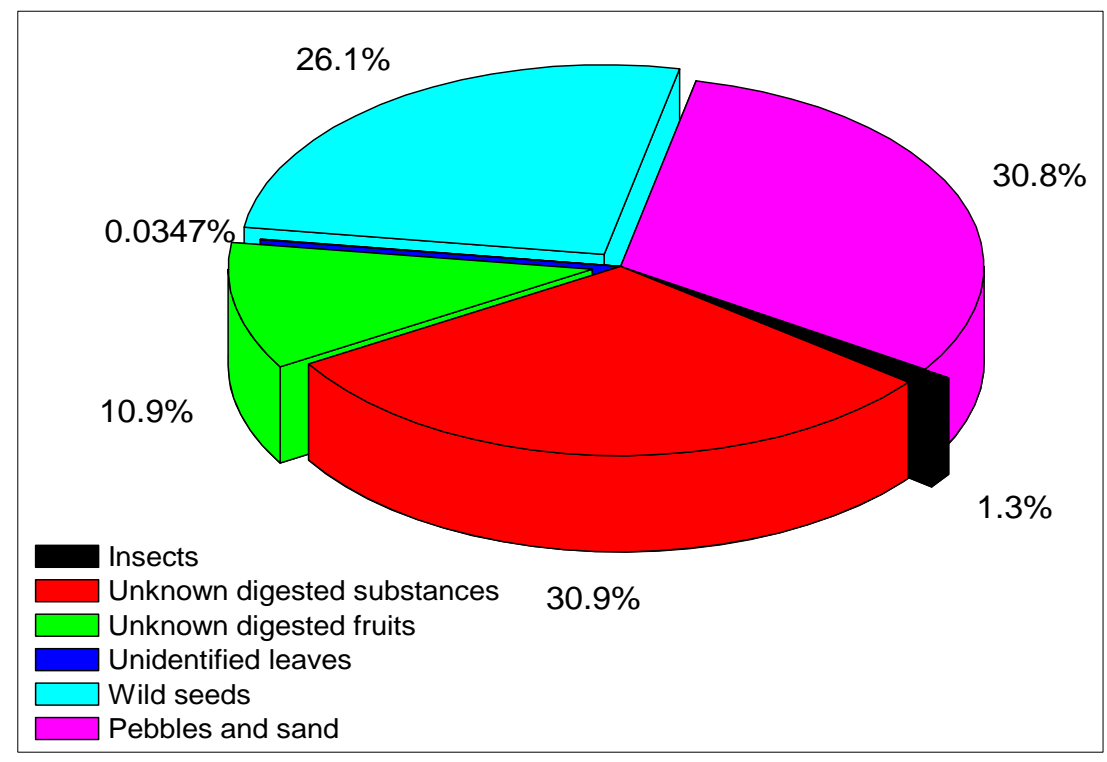

Figure 6 Proportion (\%) of the contents identified in the gizzards of Guttera pucherani

\subsubsection{Proportion of contents identified in the gizzards of Francolinus afer}

The results in Figure 7 indicate that quantitatively, wild plant seeds (19.91\%) are the most consumed compared to fragments of unknown digested fruits (16.15\%), seeds of food crops of peanuts (13.17\%) and beans (3.80\%), insect fragments $(1.43 \%)$ and Panicum caryopsis (1.10\%). Pebbles and sand, the unknown substrate digested by the birds represent respectively $22.40 \%$ and $21.96 \%$. 


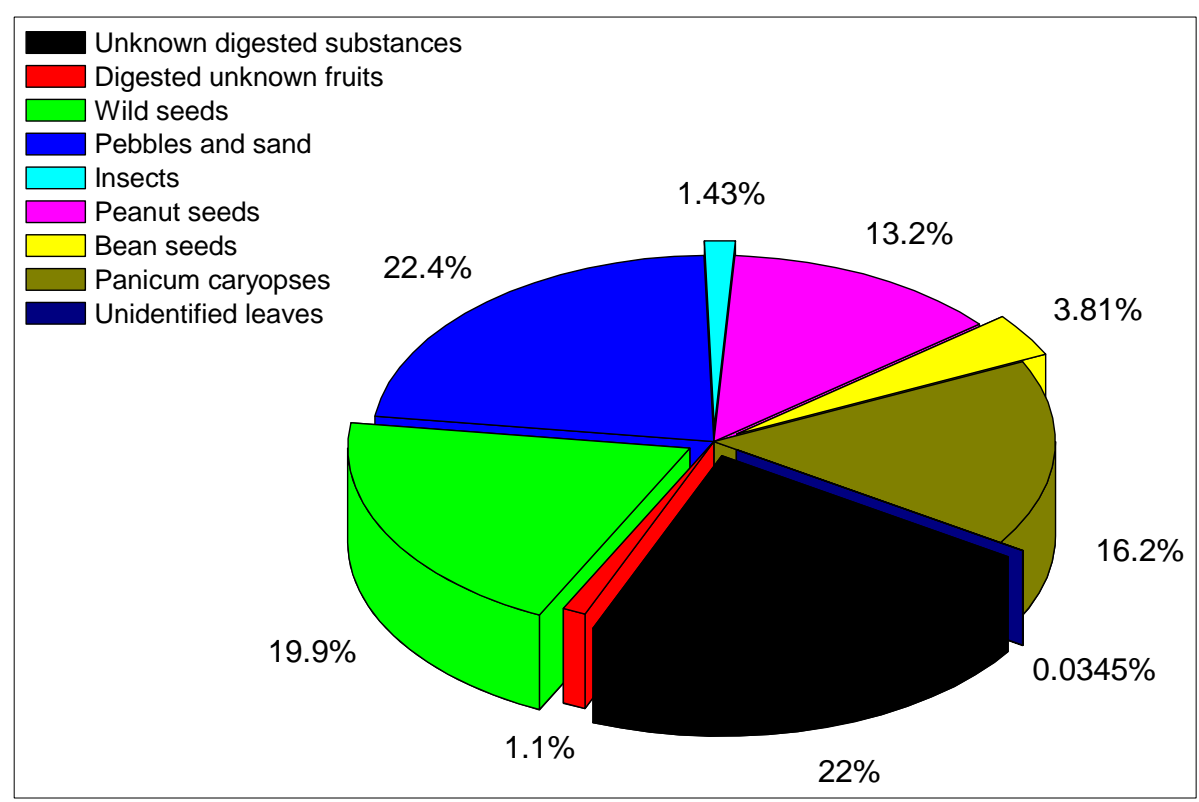

Figure 7 Proportion (\%) of the contents identified in the gizzards of Francolinus afer

\subsubsection{Proportion of contents identified in the gizzards of Francolinus coqui}

Analysis of the results in Figure 8 reveals that quantitatively, plant seeds are the most consumed (23.16\%) compared to insect fragments (21.84\%), fruit fragments (19.93\%), leaf debris $(2.04 \%)$ and flower debris (0.68\%).Unknown digested substances account for $31.84 \%$ while stones and sand account for $19.48 \%$. In general, the Phasianidae studied consume the same types of substances, namely, plant seeds, insects, fruits in different proportions. Other substances such as seeds of food crops, caryopsis of Panicum, leaf debris, flower debris were also observed in the gizzards of Phasianidae birds. Quantitatively Phasianidae consume more plant seeds and fruits than insects, leaves and flowers.

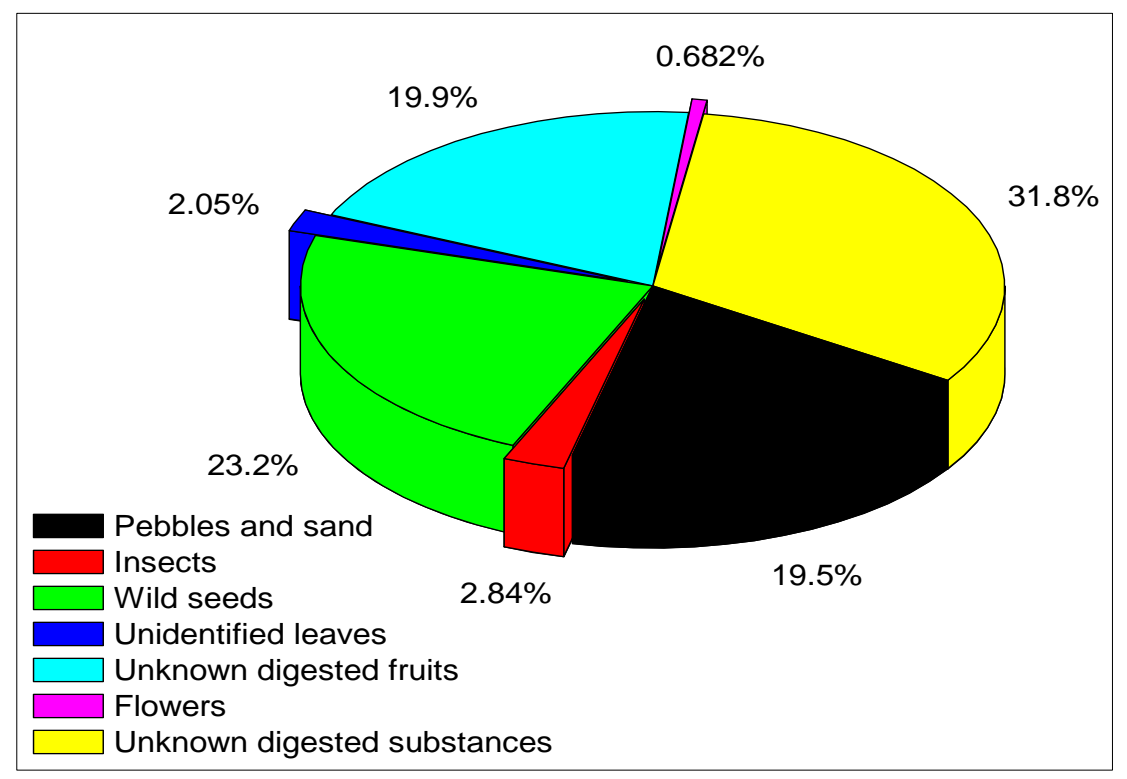

Figure 8 Proportion (\%) of contents identified in Francolinus coqui gizzards

\subsection{Variation in weight and size of birds according to sampling periods}

Variations in weight and size of bird species captured in the Bombo-Lumene Game and Wildlife Reserve according to the months of harvest are shown in Table 4. 
Table 4 Variation in average weight and size of Numididae and Phasianidae birds captured at the DCRBL

\begin{tabular}{|c|l|c|c|}
\hline Period & \multicolumn{1}{|c|}{ Species } & Weight (g) & Size (cm) \\
\hline \multirow{4}{*}{ September 2019 } & 1. Numida meleagris & 1237 & 36 \\
\cline { 2 - 4 } & 2. Francolinus afer & 334 & 25 \\
\cline { 2 - 4 } & 3. Fracolinus coqui & 315 & 23 \\
\hline \multirow{4}{*}{ Fecember 2019 } & 1. Numida meleagris & 1427 & 62 \\
\cline { 2 - 4 } & 2. Francolinus afer & 419 & 34 \\
\hline \multirow{4}{*}{ October 2020 } & 1. Numida meleagris & 1300 & 59 \\
\cline { 2 - 4 } & 2. Francolinus afer & 351 & 25 \\
\cline { 2 - 4 } & 3. Francolinus coqui & 320 & 23 \\
\cline { 2 - 4 } & 1. Francolinus afer & 395 & 30 \\
\cline { 2 - 4 } & 2. Francolinus coqui & 304 & 22 \\
\hline \multirow{3}{*}{ 3ecember 2020 Guttera pucherani } & 1480 & 65 \\
\cline { 2 - 4 } & 1. Numida meleagris & 1320 & 56 \\
\cline { 2 - 4 } & 2. Francolinus afer & 338 & 24 \\
\cline { 2 - 4 } & 3. Francolinus coqui & 293 & 20 \\
\cline { 2 - 4 } & 4. Guttera pucherani & 1530 & 69 \\
\hline
\end{tabular}

Examination of Table 4 above indicates that the average weight of the birds surveyed varies by time period and bird species. The variation in weight of individuals is related to their size. The weight of the species varies between $239 \mathrm{~g}$ (Francolinus coqui) and 1,530 g (Guttera pucherani). Numida meleagris (1427 g and $56 \mathrm{~cm}$ ), Francolinus afer (419 g and $34 \mathrm{~cm})$, Guttera pucherani $(1530 \mathrm{~g}$ and $69 \mathrm{~cm}$ ) present a great mass and size during the month of December 2019 and 2020. During the months of September and February, Numida meleagris presents respectively $1237 \mathrm{~g}$ and $36 \mathrm{~cm}$ and $1300 \mathrm{~g}$ and $59 \mathrm{~cm}$.

\subsection{General average weights and sizes of identified Numididae and Phasianidae birds}

The results visualized in figure 9 show that, on average, the average weight and size of the species of birds captured vary from one species to another. The species Guttera pucherani with $1505 \mathrm{~g}$ and $67 \mathrm{~cm}$ and Numida meleagris with $1294 \mathrm{~g}$ and $58 \mathrm{~cm}$ are the ones that present higher weights and sizes than the others.

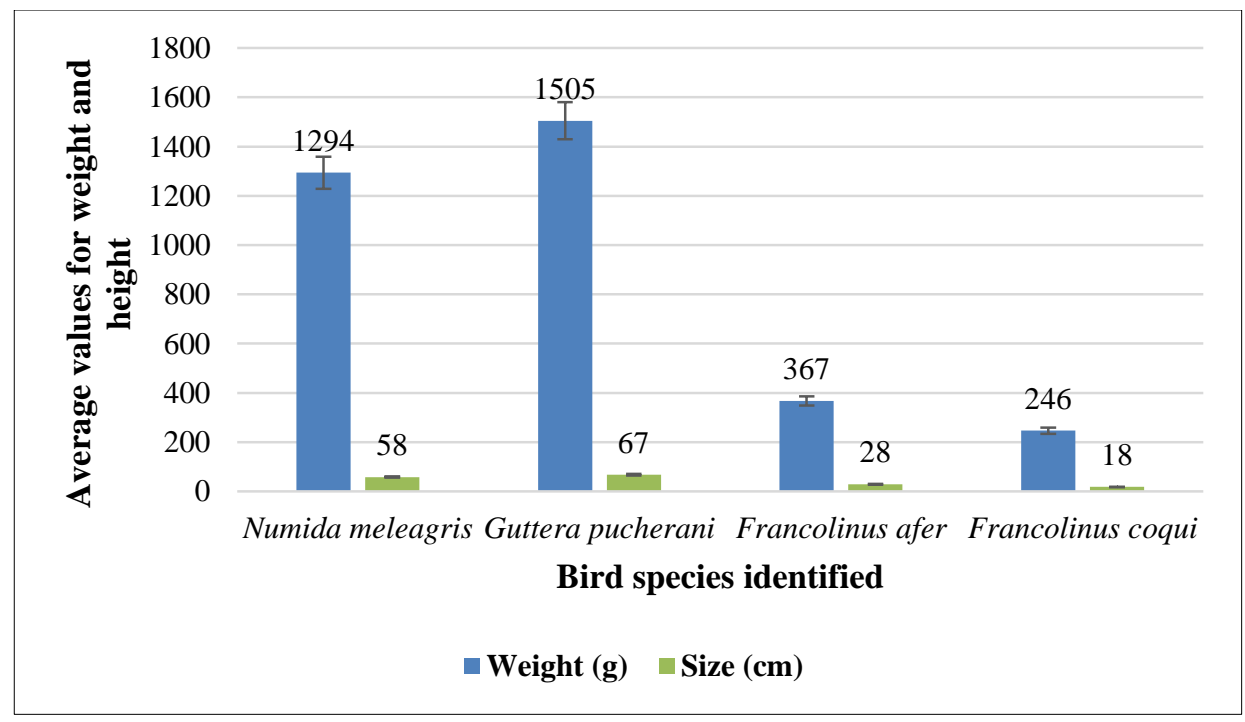

Figure 9 General averages of weights and sizes of identified Numididae and Phasianidae birds 


\section{Discussion}

Five (5) species of birds were identified in the Bombo-Lumene Hunting Area and Reserve and grouped in one order (Galliformes), two families (Numididae and Phasianidae) and three genera (Numida, Guttera and Francolinus). The birds of the Numididae family were the most numerous in terms of genera with $66.7 \%$ or two genera (Numida and Guttera) than the Phasianidae (33.3\% or one genus: Francolinus). These results confirm the annual activity reports of the protected area and the results obtained by Mbenzo [3]; [5]; [12]; [13] which indicate the presence of Numididae and Phasianidae birds in the DCRBL. At the level of genera, Francolinus with $60 \%$ or three species (Francolinus afer Statius Muller, 1776; F. coqui Smith, 1836 and F. streptophorus Ogilvie-Grant, 1891) was the most representative followed respectively by the genera Numida and Guttera with one species or $20 \%$. Compared to the aforementioned researchers who recorded only the species Numida meleagris in the order Galliformes, our study identifies four other species, namely, Guttera pucherani (Numididae), Francolinus afer, Francolinus coqui and Francolinus streptophorus (Phasianidae).

Of 468 specimens identified, 105 were observed in the DCRBL, the most numerous in treeless areas (36.1\%) and the least numerous in forest galleries (1.9\%). Of the species captured (363), the most numerous were in Mbankana in food crop fields (48.89\%) and the least numerous in Nsuni in forest galleries and plateaus (0.5\%). The specific abundance index reveals that Francolinus afer was the most dominant species in the sites studied with 364 individuals or $78 \%$ compared to Numida meleagris with 58 specimens or 12\%, Francolinus coqui with 42 individuals or $9 \%$, Guttera pucherani with 3 specimens or $1 \%$. Francolinus streptophorus presents a low percentage $(0.2 \%$ or one individual). The different periods of the field trip were a determining factor in the study of the seasonal fluctuations of the birds. Indeed, we found that in the month of February, there were many birds observed and captured (198 specimens) that in the months of October where there was a decline ( 99 specimens); December with a sharp decline (65 specimens) and finally in September where we observed a very sharp decline in the capture of said birds (41 specimens).

The weight and size of these birds varied from one species to another within the family. Their overall averages were $1294 \mathrm{~g}$ and $58 \mathrm{~cm}$ for Numida meleagris, $1505 \mathrm{~g}$ and $67 \mathrm{~cm}$ for Guttera pucherani, $367 \mathrm{~g}$ and $28 \mathrm{~cm}$ for Francolinus afer and finally $246 \mathrm{~g}$ and $18 \mathrm{~cm}$ for Francolinus coqui. These values are close to the averages mentioned by Borrow and Demey [8]; [9]. With regard to these averages, Numida meleagris and Guttera pucherani (Numididae) are the large birds compared to the Phasianidae studied. Also, their sizes and weights are close to those of commercialized chickens (Wilki, Pluvera, Calisa, Bare chicken) much appreciated by consumers in the city of Kinshasa [14] and other parts of the Democratic Republic of Congo [15], hence the interest of a domestication trial.

The results of the analysis of the stomach contents of the birds showed that they consume almost the same types of substances, notably insect debris, seeds of wild and food plants, fragments of leaves, fruits and flowers, but in different proportions. From the point of view of quantity, seeds of wild plants $(22.60 \%$ and $22.06 \%)$ were the most consumed by all Numididae examined followed by insect debris (1.30\% and $1.26 \%)$. These results are close to those of the works carried out by Fabiola [11]; Schouteden [16], [17], [18], [19], [20], [21]; [22]; [23] and inform that the food of Numidae and Phasianidae birds in the Bombo-Lumene Hunting Estate and Reserve is essentially formed of plant and animal elements. The diversity of food found in the stomach contents of the birds thus reveals that food resources are abundant in the environments where these birds live, thus sparing them from food competition.

\section{Conclusion and Perspectives}

This study identified some species of Numididae and Phasianidae birds in the Bombo-Lumene Hunting Estate and Reserve in D.R. Congo. The weight, size and diet of these birds were also targeted and studied for a domestication trial. Indeed, the results of the available diet of Numidae and Phasianidae studied associated with factors such as size and body weight, mode of nutrition on the ground and adaptation to tropical climatic conditions, the ever-increasing demand for this resource in the urban center constitutes an opportunity for a trial of their domestication outside the protected area in D.R Congo.

The results obtained indicated openings tending to approach the identification of the whole diversity of these birds within the protected area, to the domestication of some species already experimented elsewhere. Similarly, the impact of these birds in the fields (cassava, maize, cowpeas, etc.) also appears to be an opening for future research. 


\section{Compliance with ethical standards}

\section{Acknowledgments}

The authors would like to thank the hunters from the villages surrounding the Hunting Estate and Reserve of BomboLumene for their availability and help in sampling the birds, as well as those in charge of the Laboratory of Aquatic Environment Studies at the Superior Pedagogical Institute of the Gombe in Kinshasa for their collaboration in analyzing the birds' diet.

\section{Disclosure of conflict of interest}

The authors of this article report no conflicts of interest in this work.

\section{References}

[1] Dorst J. Les techniques d'échantillonnage dans l'étude des populations d'oiseaux. Muséum National d'Histoire Naturelle, Paris. 2008; 180-202.

[2] Desrochers A, Darveau M. Faune aviaire: Recherches sur les oiseaux forestiers. Le Naturaliste Canadien. 2001; 125(3): 36-40.

[3] Mbenzo A. Inventaire systématique de l'avifaune de la réserve et domaine de chasse de Bombo-Lumene, Mémoire de Licence en Sciences Agronomiques, Université de Kinshasa, R.D Congo. 2002; 43.

[4] Kayumba M, Lubini C, Kidikwadi E, Habari JP. Etude floristique de la végétation de la formation mature du Domaine et Réserve de Bombo-Lumene (Kinshasa / RD Congo). International Journal of Innovation and Applied Studies. 2015; 11(3): 716-727.

[5] Punga JK, Ifuta BN. Recent data on birds of Kinshasa in Democratic Republic of Congo. J. agr. Sci. Technol. 2015; A5: 218-233.

[6] Pwema KV, Mbomba BN, Kikala AE, Lusasi SW, Micha J-C. Utilisation des alevins de Schilbe mystus (Linné, 1758) (Siluriformes: Schilbeidae) dans la lutte biologique contre les larves de moustiques. Congo science. 2019; 7(1): 83-86.

[7] Lusasi SW, Manza KR, Bipendu MN, Munganga KC, Kavumbu MS, Gafuene NG, Pwema KV. Analysis of the ichtyological composition of smoked fish sold in the Liberté and Gambela markets in Kinshasa, Democratic Republic of Congo. Agricultural Science. 2020; 2(2): 69-79.

[8] Borrow N, Dewey R. A guide of the birds of Western Africa Princeton. 2001.

[9] Sinclair I, Ryan P. Birds of Africa south of the Sahara. Second edition, Ed. Struik Nature, Malaysia. University Press, Princeton and Oxford. 2010.

[10] Mulotwa M. Introduction à l'étude du régime alimentaire de Ploceus cucullatus (REICHNEW) à Kisangani (Haut Zaïre) Ordre des Passériformes, Famille. Ploceidae. Monographie en Sciences Biologiques, Université de Kisangani, R.D Congo, 41 p. Disponible sur. 2007.

[11] Fabiola K. Contribution à l'étude du régime alimentaire de Brachycope anomala Reichnow, 1932 (Passeriforme, Ploceidae) à Kisangani (RDC). Travail de Fin de Cycle en Sciences Biologiques, Université de Kisangani, R.D Congo, 48 p. Disponible sur. 2013.

[12] Maninga V. Contribution à l'étude éco éthologique de la pintade (Numida meleagris) du Domaine de Chasse et Réserve de Bombo-Lumene. Travail de Fin de Cycle en Sciences Biologiques et Techniques Appliquées, Institut Supérieur Pédagogique de la Gombe, R.D Congo. 2015; 46.

[13] Makunga M. Inventaire des oiseaux dans différents habitats du Domaine de Chasse et Réserve de Bombo-Lumene (RD Congo). Mémoire de Licence en Sciences Biologiques et Techniques Appliquées, Institut Supérieur Pédagogique de la Gombe, R.D Congo. 2018; 25.

[14] Masua TB, Lusasi SW, Munganga KC, Wumba MP, Kavumbu MS, Pwema KV. Inventory of fresh fish marketed in the markets of Kinshasa in the Democratic Republic of Congo (case of the Gambela and Matete markets). International Journal of Applied Research. 2020; 6(4): 102-108. 
[15] Lusasi SW, Makiese MP, Kunonga NL, Munganga KC, Kavumbu MS, Pwema KV. Proportion de vente des poissons frais locaux et importés dans les marchés de Kinshasa en République Démocratique du Congo (cas des marchés de la Liberté de Masina et Central de Kinshasa). Journal of Applied Biosciences. 2019; 141: 14353 -14363.

[16] Schouteden H. Faune du Congo belge et du Rwanda Urundi: Oiseaux Passereaux. Annales du Musée Royal du Congo Belge, Tervuren, Sciences zoologiques. 1954-1957; 57(8).

[17] Schouteden H. Faune du Congo-Belge et du Ruanda-Urundi: Oiseaux Passereaux. Annales du musée à l’Ornithologie du Zaïre. 1959.

[18] Schouteden H. Faune du Congo belge et du Rwanda Urundi: Oiseaux Passereaux. Annales du musée royal du Congo belge, Tervuren, Vol. 89, Série 8, Sciences Zoologiques. 1960.

[19] Schouteden H. La faune Ornithologique du territoire de Mushie (District du Lac Léopold II- Contribution à l’Ornithologie de la République du Congo II). Musée Royal de l’Afrique Centrale, Tervuren, Belgique, Documentation Zoologique, $\mathrm{n}^{\circ}$ 2. 1962.

[20] Schouteden H. La faune Ornithologique des districts du Bas-Uélé et du Haut Uélé: Contribution à l'Ornithologie du Zaïre. 1963.

[21] Schouteden H. La faune Ornithologique de la province du Kasaï-contribution à l'Ornithologie de la République du Congo. Musée Royal de l’Afrique Centrale, Tervuren, Belgique, Documentation Zoologique, nº 6. 1964.

[22] Kadeéito CB. Contribution à l'alimentation de l'élevage villageois de la pintade locale dans le Département du Borgou (Nord-Est du Bénin). Mémoire de Licence en Production animale, Faculté Universitaire des Sciences Agronomiques, Gembloux, Belgique. 2004; 45.

[23] Biya MJ. Etude écologique du Francolin à gorge rouge Pternistis afer Muller dans les faubourgs de Kinshasa. Mémoire DEA en Sciences Biologiques, Université de Kinshasa, R.D Congo. 2007; 44. 